KATHOLIEKE UNIVERSITEIT

The conservation value of church forests is linked to historical deforestation patterns

\title{
Raf Aerts
}

Division Forest, Nature and Landscape

Department Earth and Environmental Sciences

K.U.Leuven

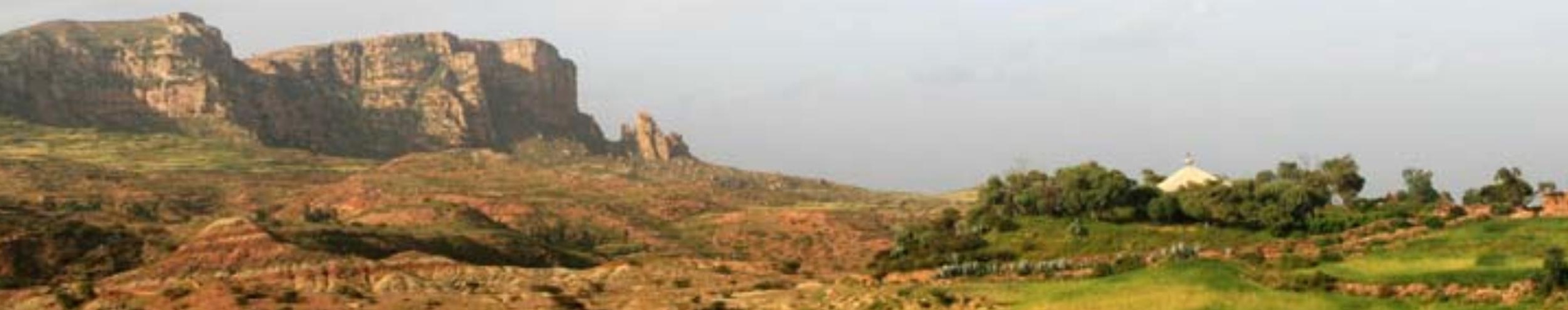




\section{Suggested citation}

Aerts R., Pankhurst R., Van Overtveld K., November E., Hermy M. and Muys B. 2008. Historical deforestation patterns and the conservation value of church forests in the northern Ethiopian highlands. International Conference Mountain Forests in a Changing World. Advances in Research on Sustainable Management and the Role of Academic Education. UNI BOKU Vienna, April 2-4, 2008. Book of abstracts, p. 14

See also

http://www.biw.kuleuven.be/lbh/lbnl/forecoman/eng/publications.asp\#1 
- Limited capacity for migration

- Altitudinal gradients limit species ranges

- Physical barriers against dispersal

- Natural islands of biodiversity

- Diversity island size

- Vulnerability to species loss increases

- Effects of climatic change

- Effects of habitat fragmentation

- Conservation

- Large fragments

- Small habitat patches

- Relictual vegetation

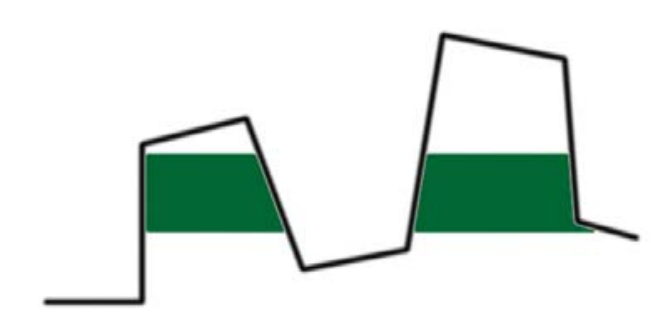

Original range

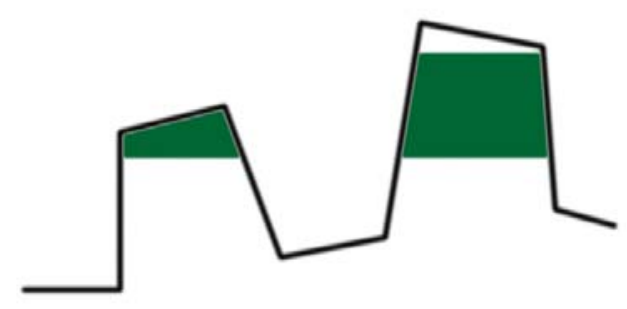

Range shift under climatic change

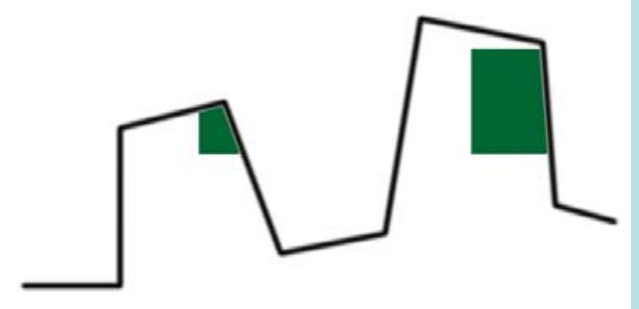

Habitat loss due to deforestation 


\section{Ecotogical" Zones in Africa: (pre)montane zones in Ethiopia}

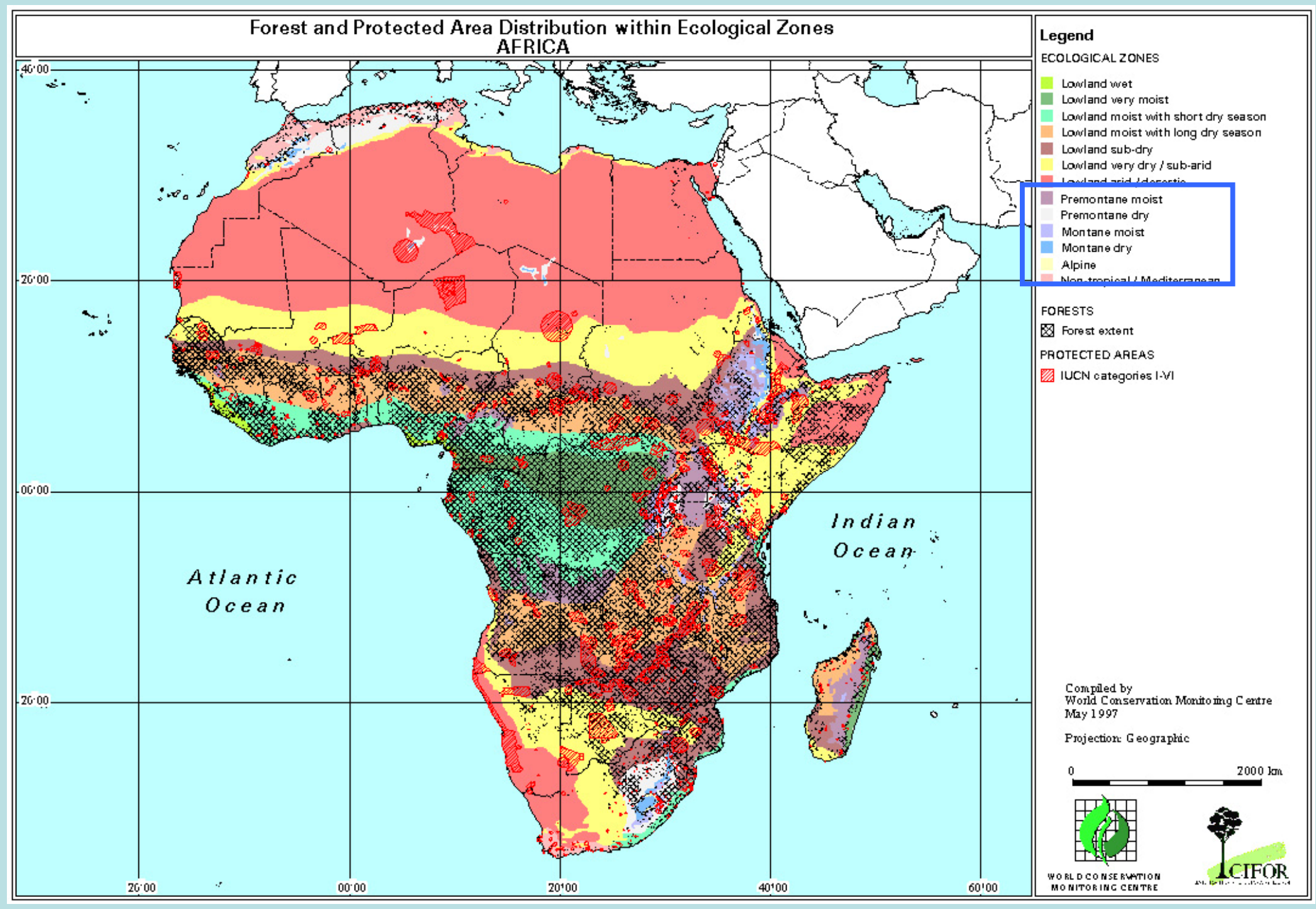




\section{Ethiopia. where have the mountain forests gone?}

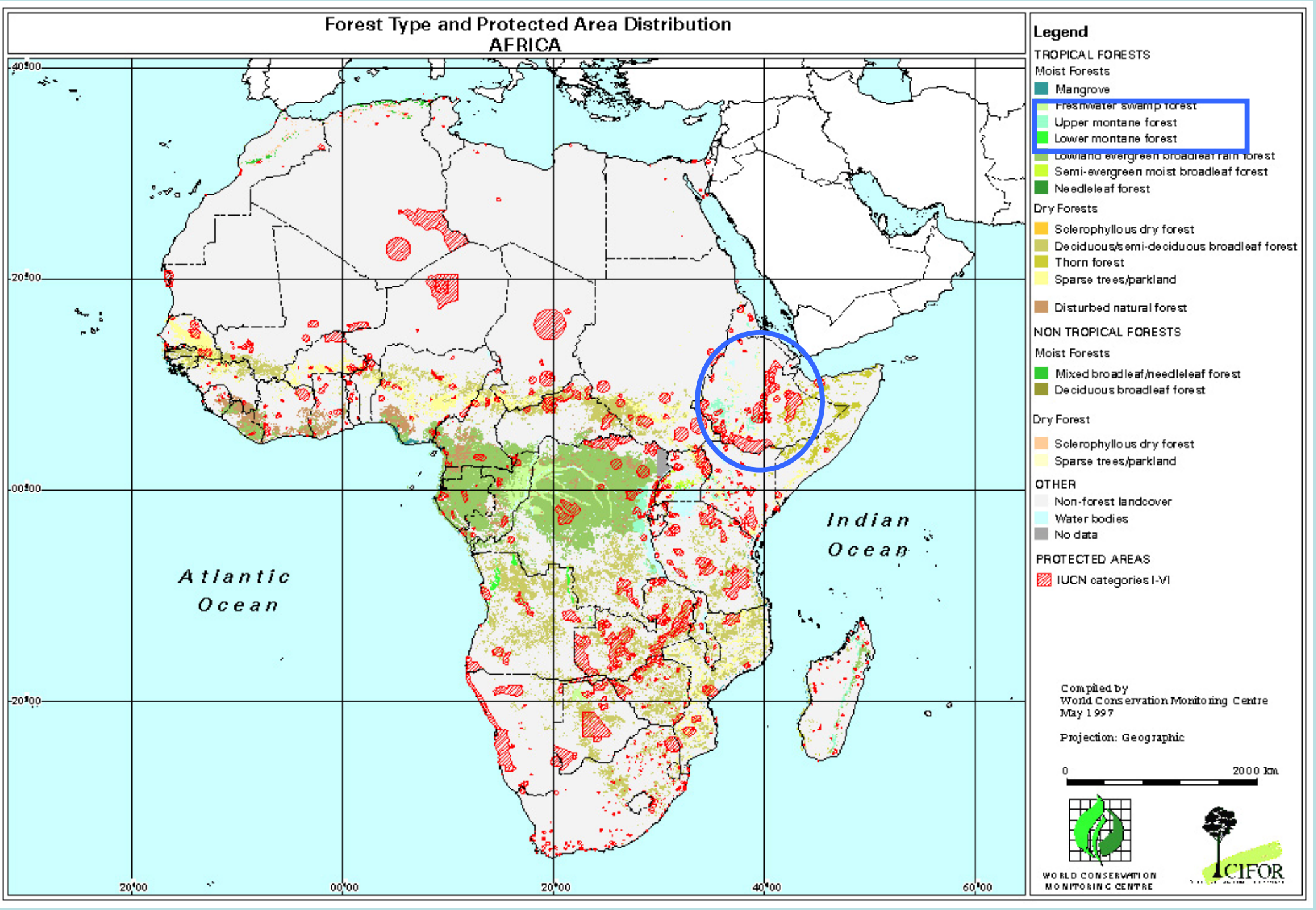




\section{Northem hightands of Ethiopia: Landsat TM - blue is forest}

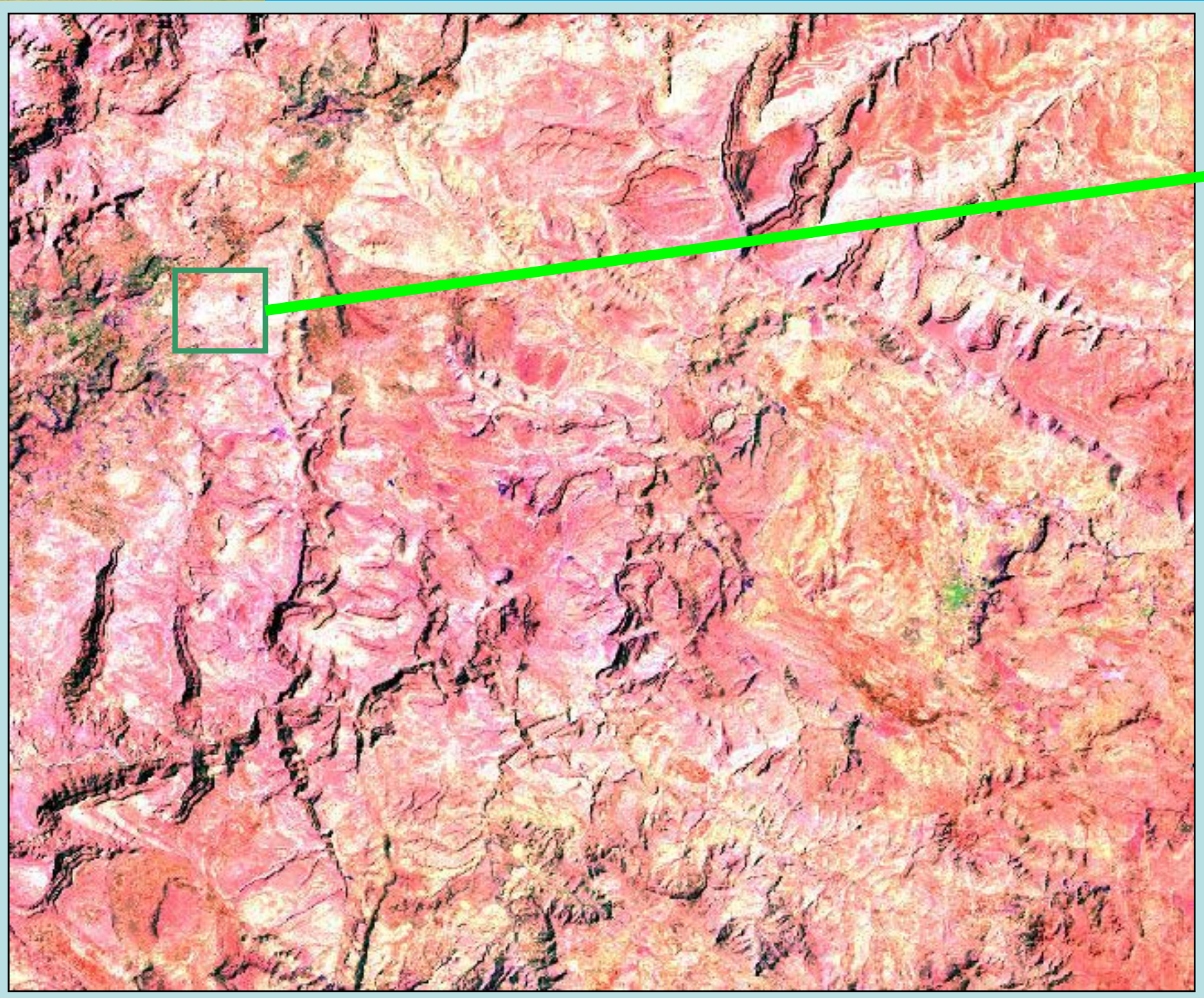




\section{Forest fragments: church forests...}
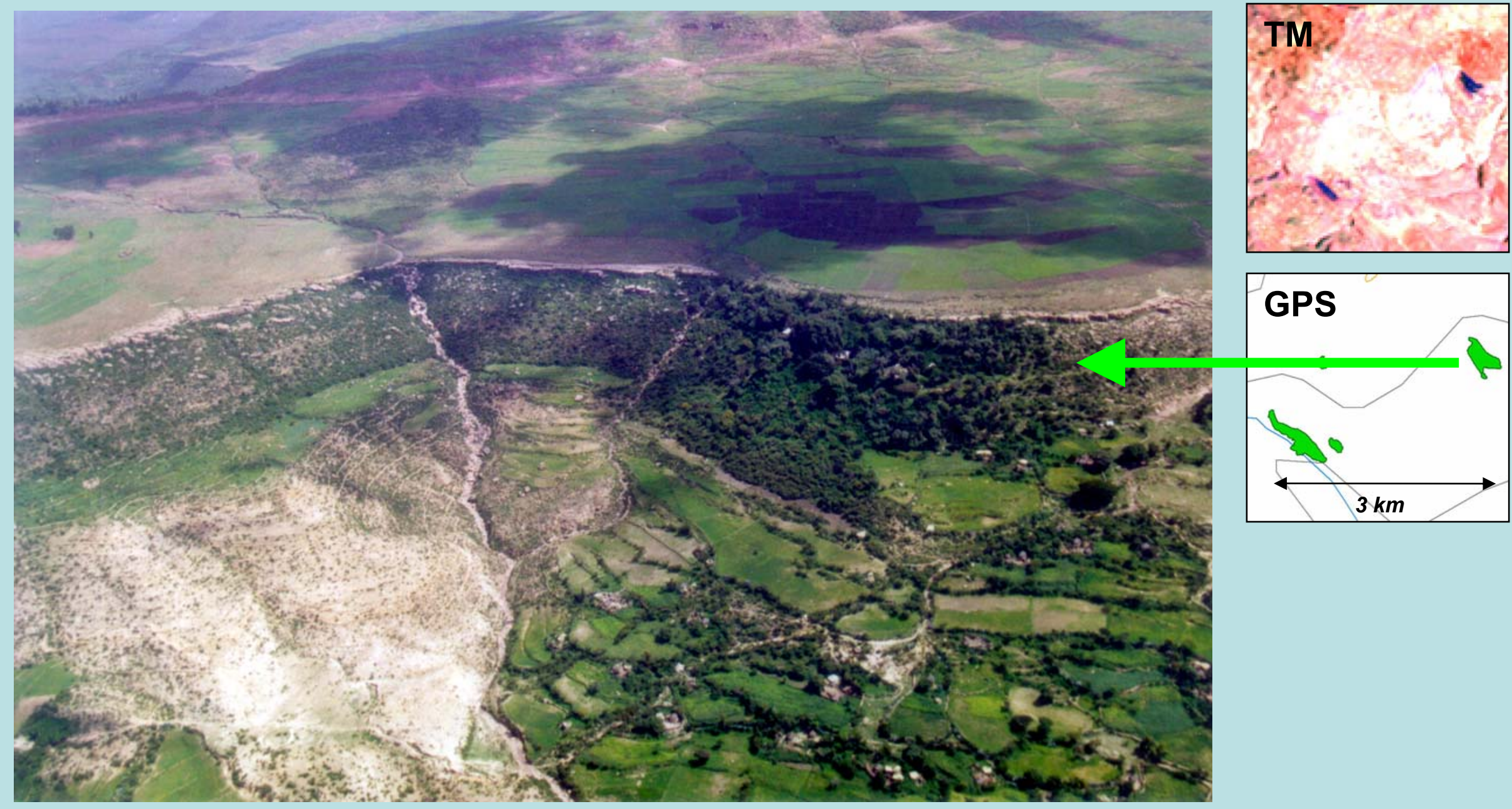


\section{...matmatix of cropland and degraded semiarid savanna}

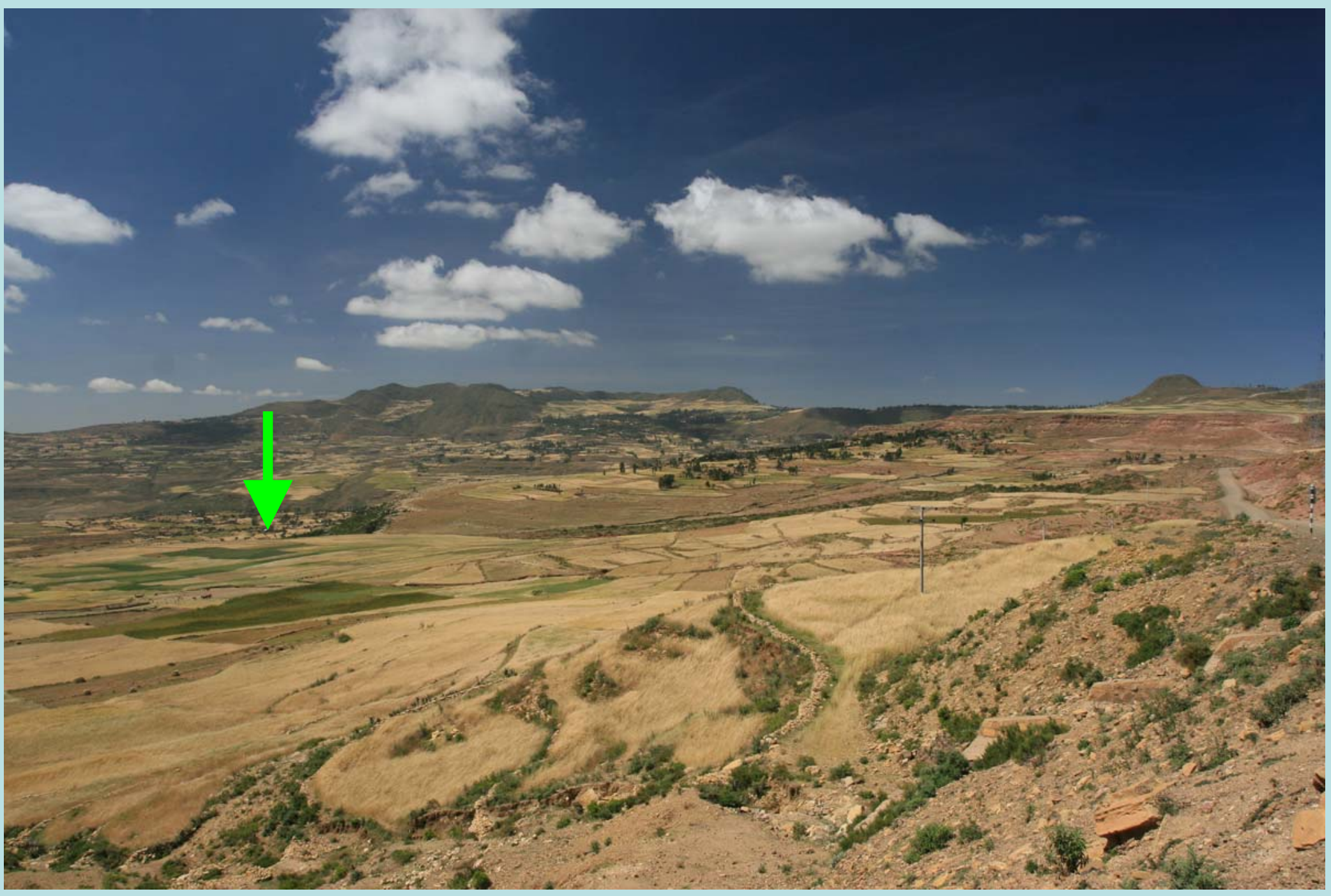




\section{Historical plant communities}

- Until 2500 years ago

- Undifferentiated or dry monodominant Afromontane forest (Friis 1992)

- Juniperus procera with Afrocarpus falcatus (Pencil cedar-Yellowwood)

- $500 \mathrm{BC}$

- Forest clearance

- Dodonaea and Rumex

- 1200-1400 AD

- Grass and frequent fires

- 1400-1700 AD

- Secondary forest

- Juniperus with Olea and Celtis

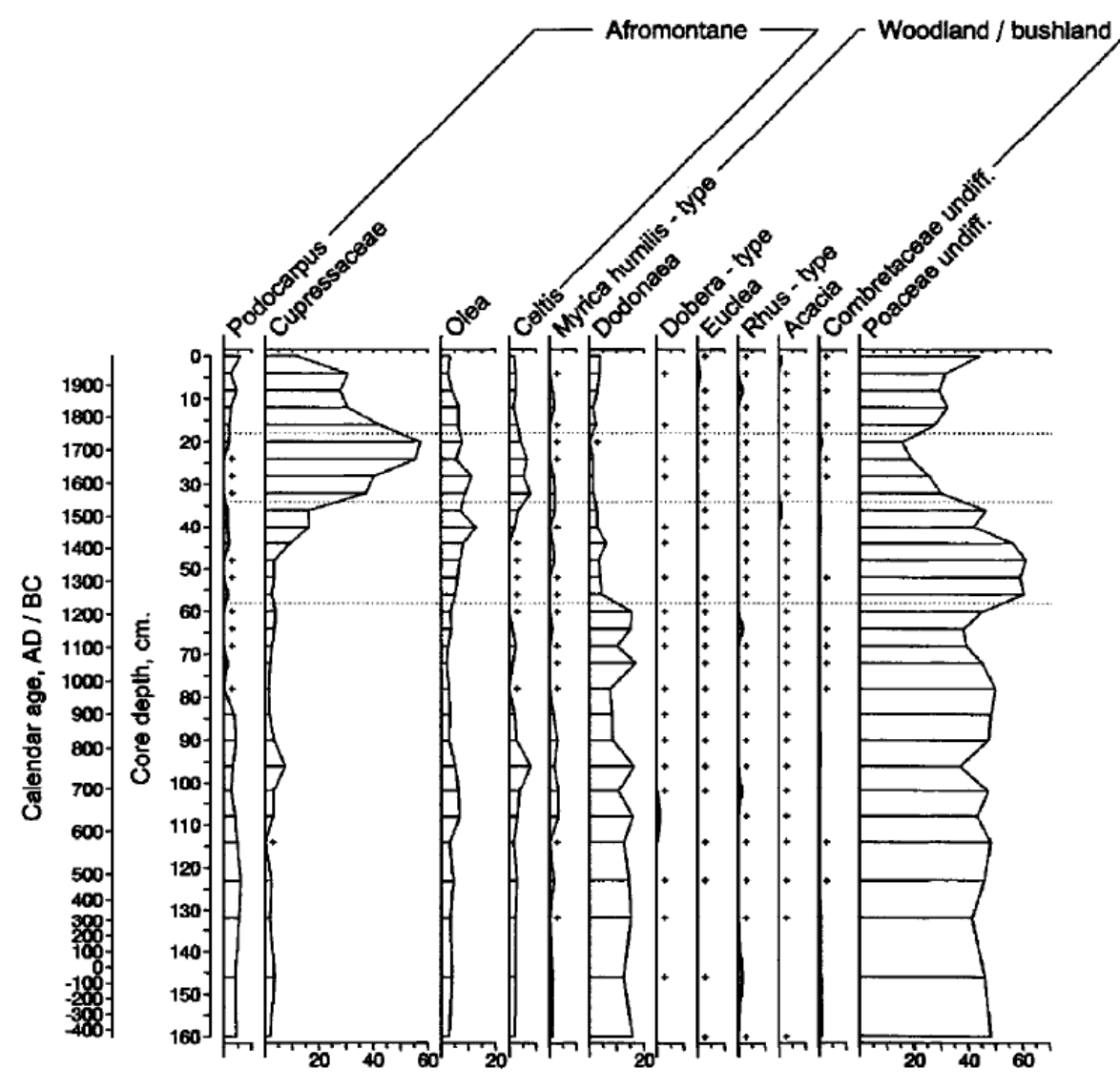

Percentage pollen and chlorophyte algal stratigraphy of Lake Hayk core HYK99-1. Darbyshire et al. (2004) The Holocene 13(4):537-546 (DOl:10.1191/0959683603hl644rp) 


\section{Nature Precedings : doi:10.1038/npre.2008.1786.1 : Posted 9 Apr 2008 \\ Forest plant communities today}

- North (Central Tigray)

secondary forest

[Aerts et al. 2006: 10 forests]

- Moist Afromontane forest with Faidherbia, Celtis and Pterolobium

- Dry Afromontane forest with Olea, Acacia and Combretum

- Shrub savanna with Acacia and Echinops

- South (South Gondar) degraded primary forest

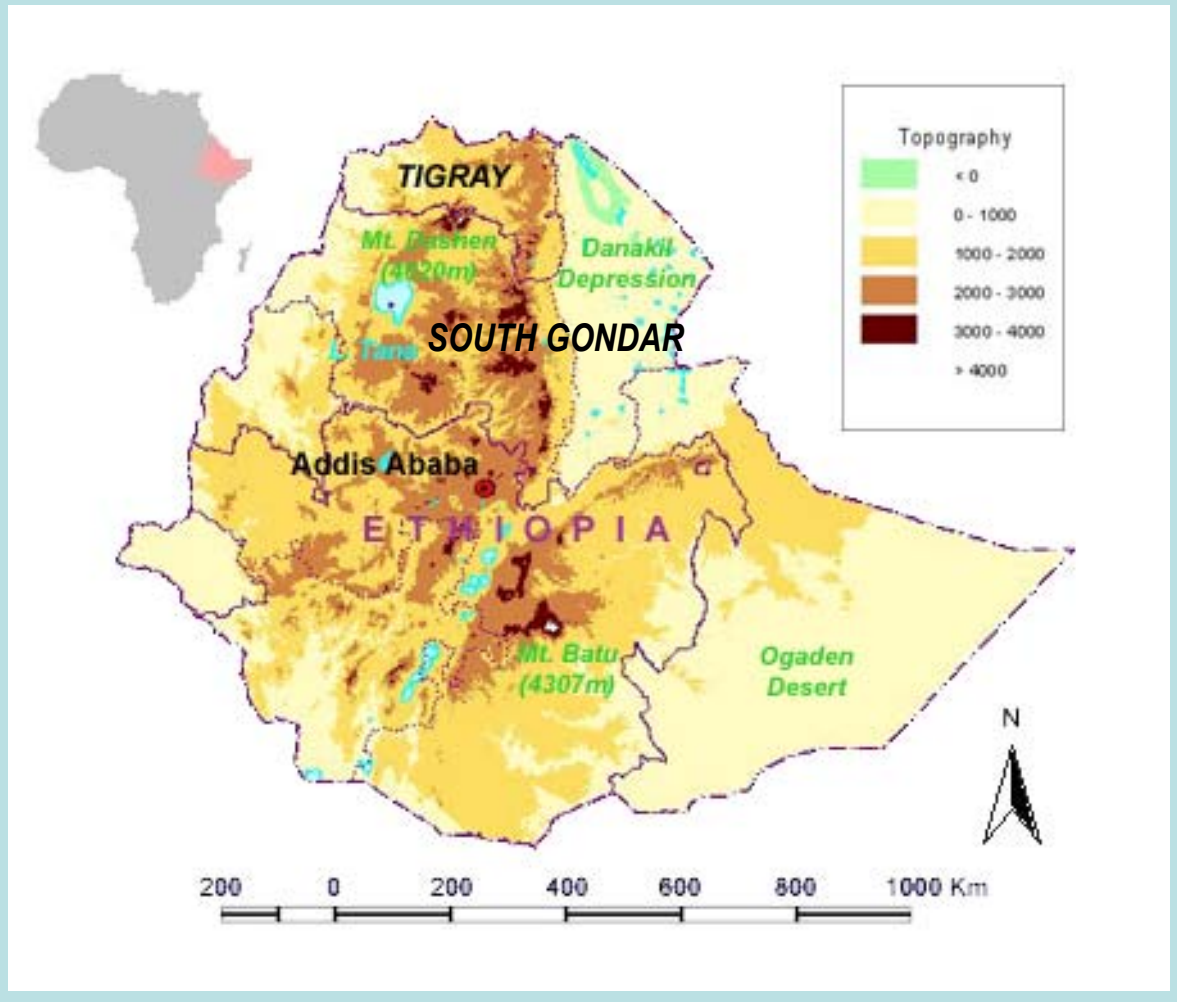

[Alemayehu Wassie 2007: 28 forests]

- Afromontane forest with Juniperus, Olea and Maytenus 
- Conservation value and management

- depend on what is actually conserved in church forests

- e.g. conservation (primary forest) vs. restoration (secondary forest)

- Not all church forests are the same

- not necessarily "the original forest vegetation" (often said so)

- Remarkable difference between north and south

- Is this also reflected in fragment area and spatial allocation? (cfr. "larger fragments or better connectivity = better conservation")

- If so, is this a general trend (more and larger fragments in the south)?

- Things to know to solve this question:

- Where are the forests in the highlands?

- What are the forest sizes and how much forest is really left? (forest cover is usually estimated at $4 \%$ )

- What are the spatial characteristics of the forests? 


\section{Methods: Google Earth/GIS}

- Northern highlands

- 8 sample blocks

- 0.5 million ha

- High-resolution satellite images (pixel resolution $0.8 \mathrm{~m}$ )

- Detected and digitized all 394 church forests

- (There were more churches than church forests - not all churches have old forest)

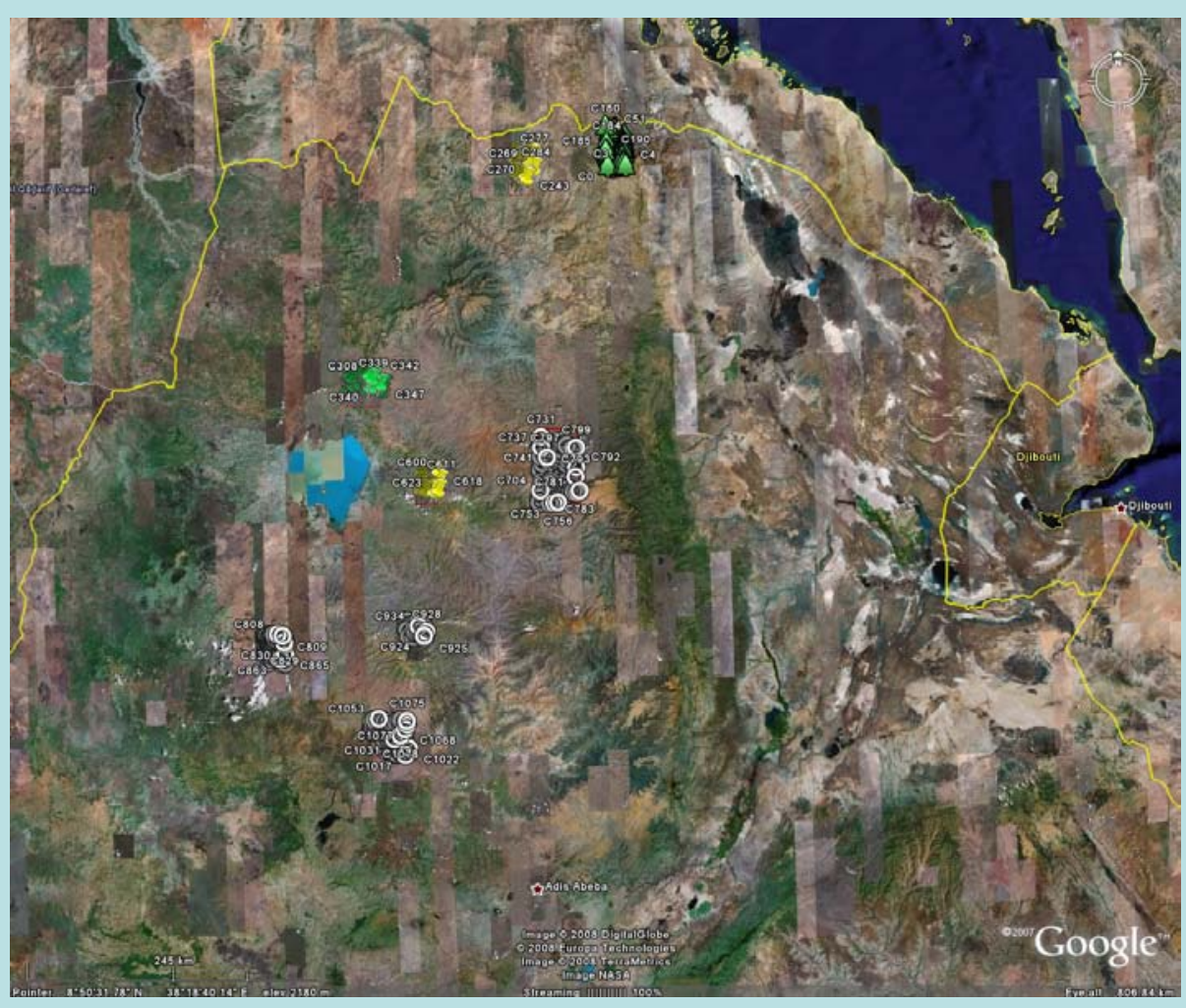




\section{Example: Debre Tabor}

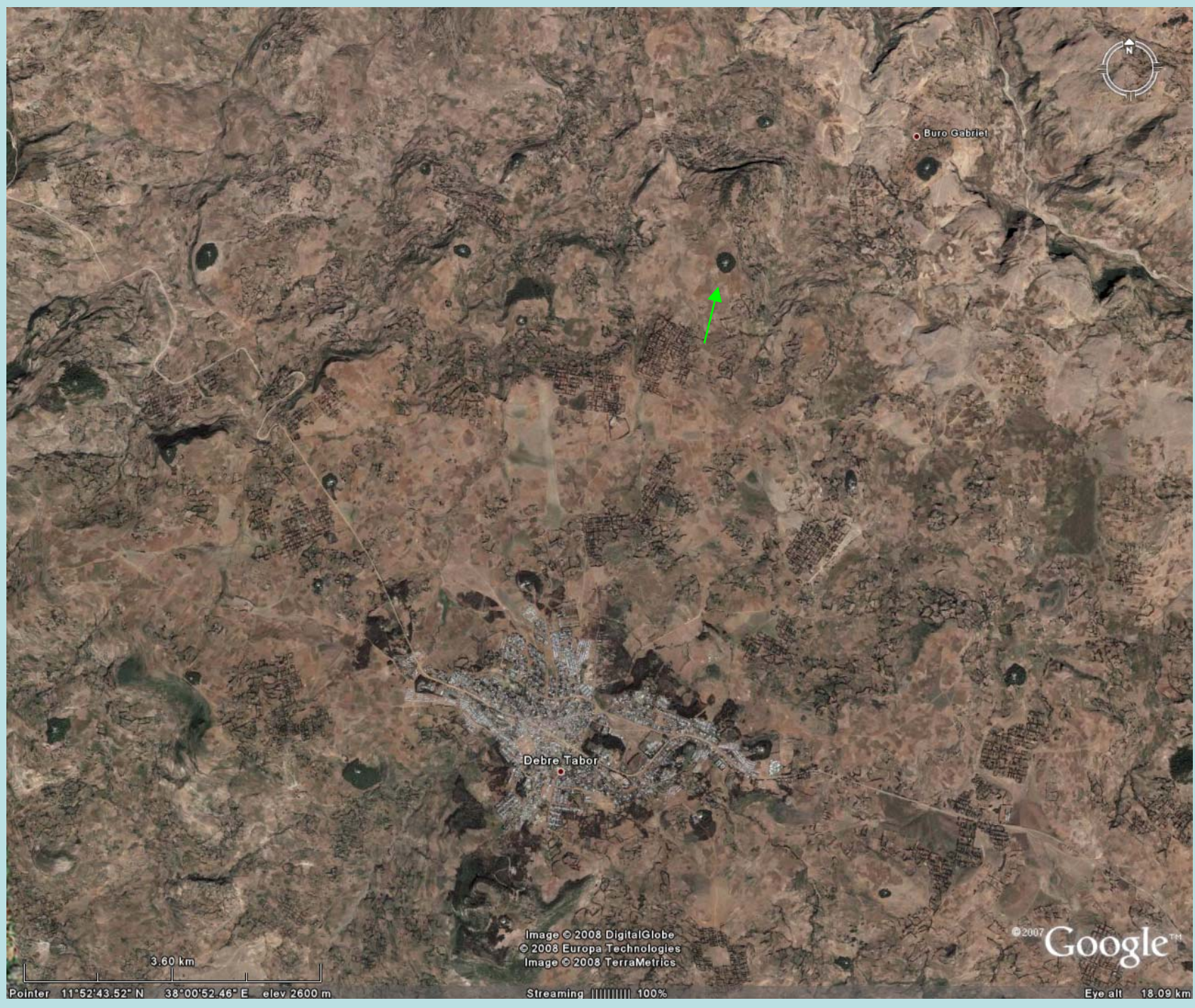




\section{Example: Debre Tabor}
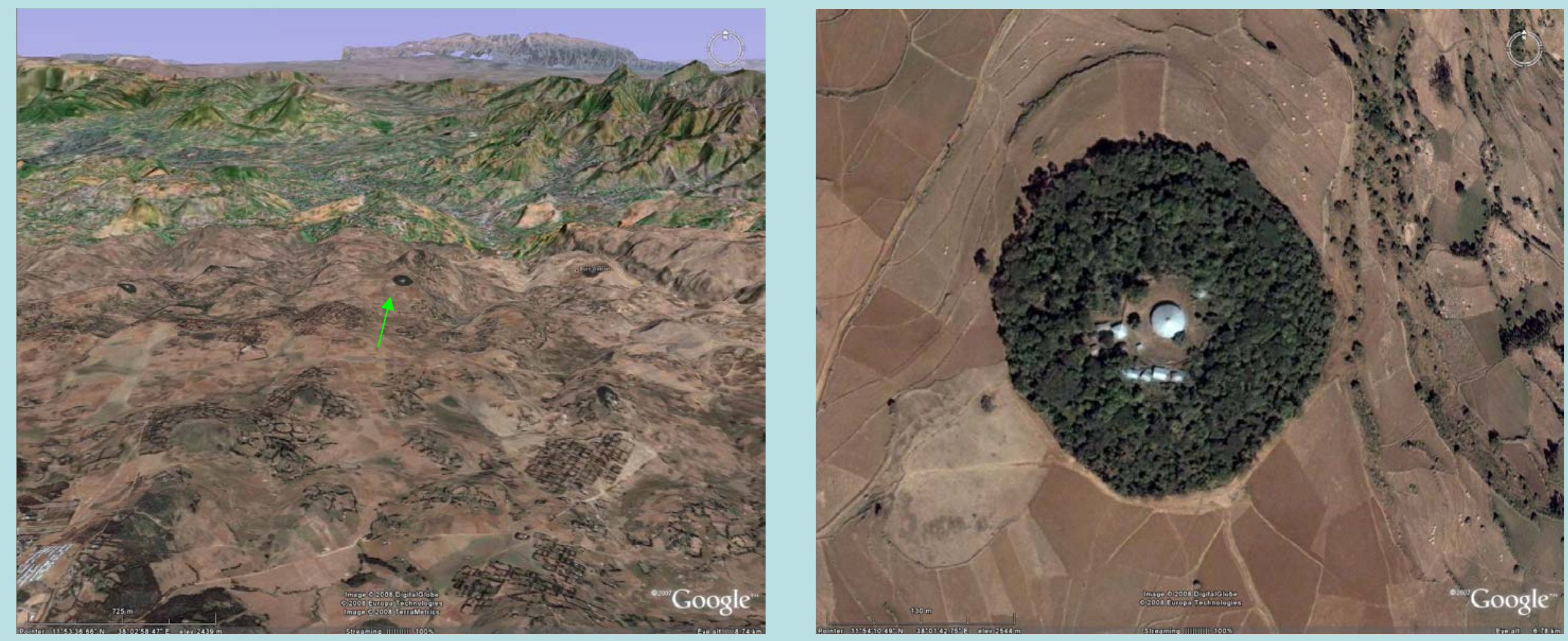


\section{Example: Debre Tabor}
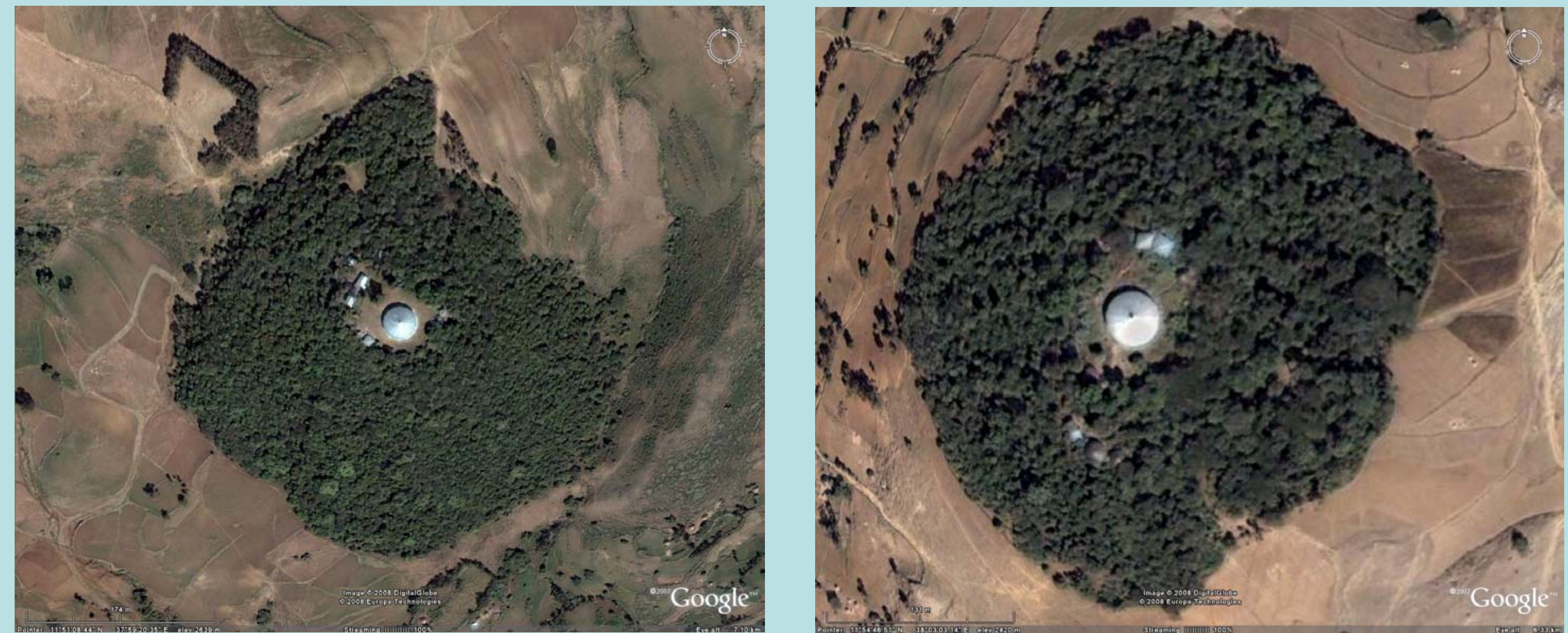


\section{Example: Debre Tabor}
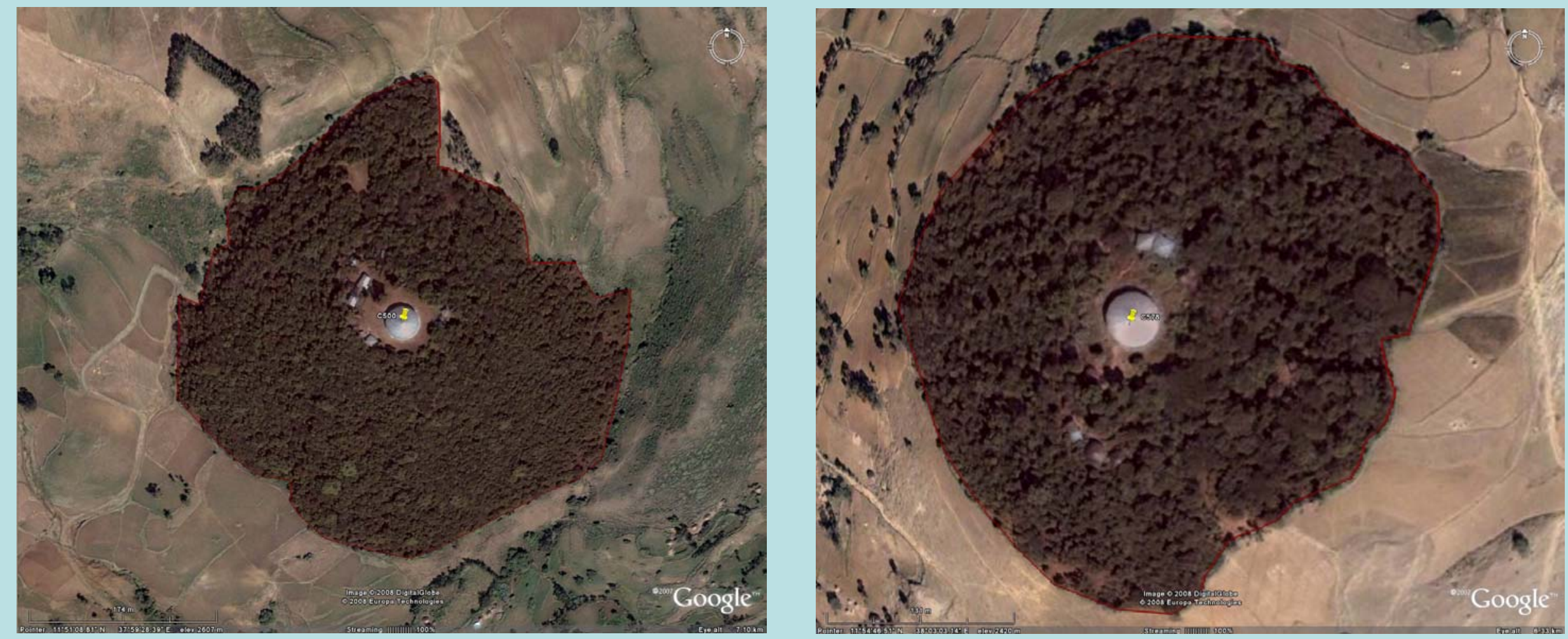

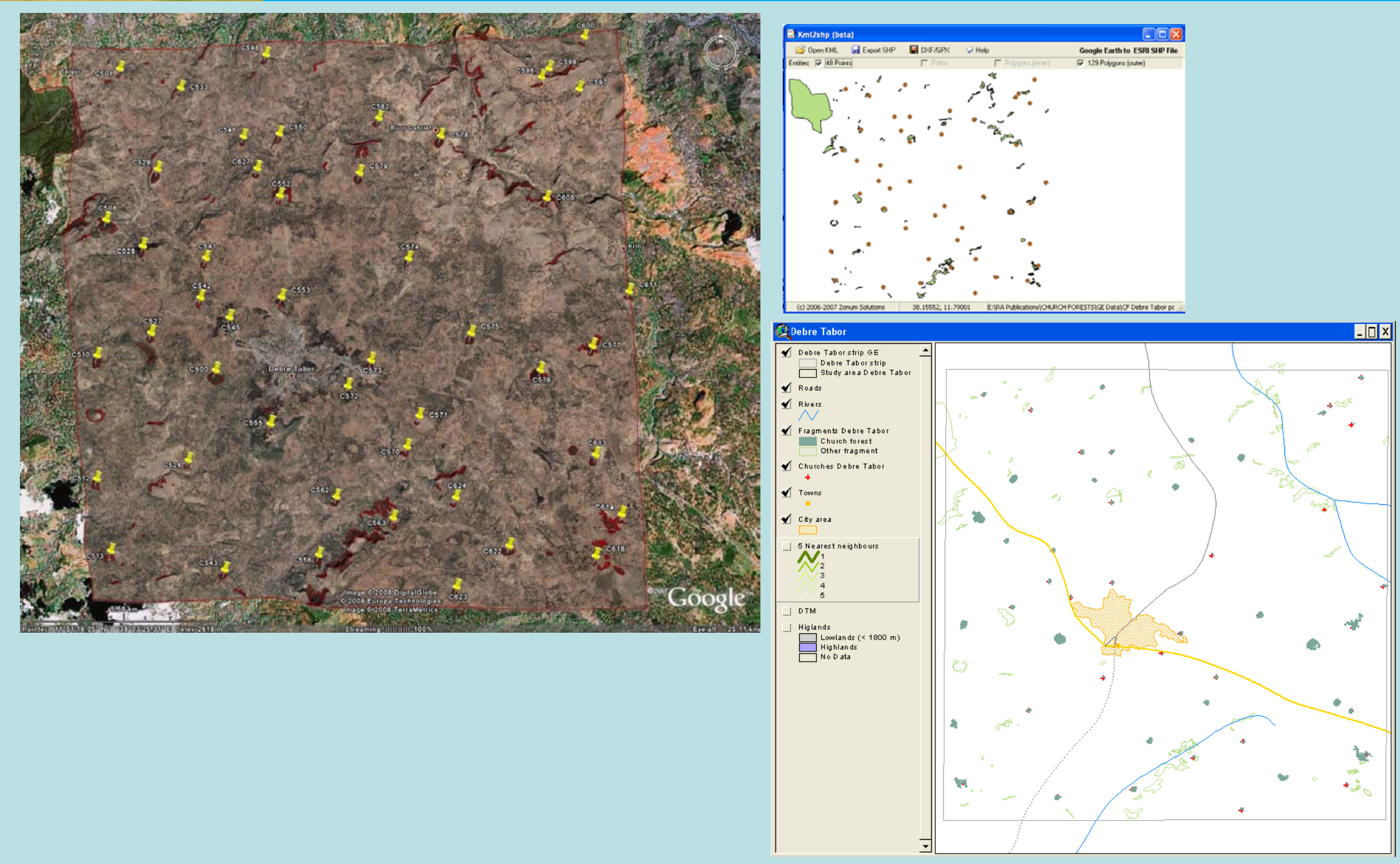
- Fragment and landscape metrics (Arcview GIS: Spatial Analyst, Patch Analyst)

- Area

- Patch area (ha)

- Patch core area (ha; 50 m internal buffer from edge and church)

- Density

- Patch density (patches per ha)

- Edge density $(\mathrm{m} / \mathrm{ha})$

- Core index (\%)

- Forest index (\%)

- Shape

- Perimeter-area ratio $\left(\mathrm{m} / \mathrm{m}^{2} ; \mathrm{PAR} ; 0.02\right.$ for a circle with $r=100 \mathrm{~m})$

- Shape index ( P $/ \sqrt{ } A$ : 1 circle; $>1$ more complex shapes)

- Fractal dimension ( 2InP/InA: 1 simple - 2 complex)

- Isolation

- Nearest neighbor distance $(\mathrm{m})$

- Configuration

- $\quad$ Aspect (via overlay with DTM)

- Slope $\left({ }^{\circ}\right)$

- $\quad$ Church to patch centroid distance $(\mathrm{m})$

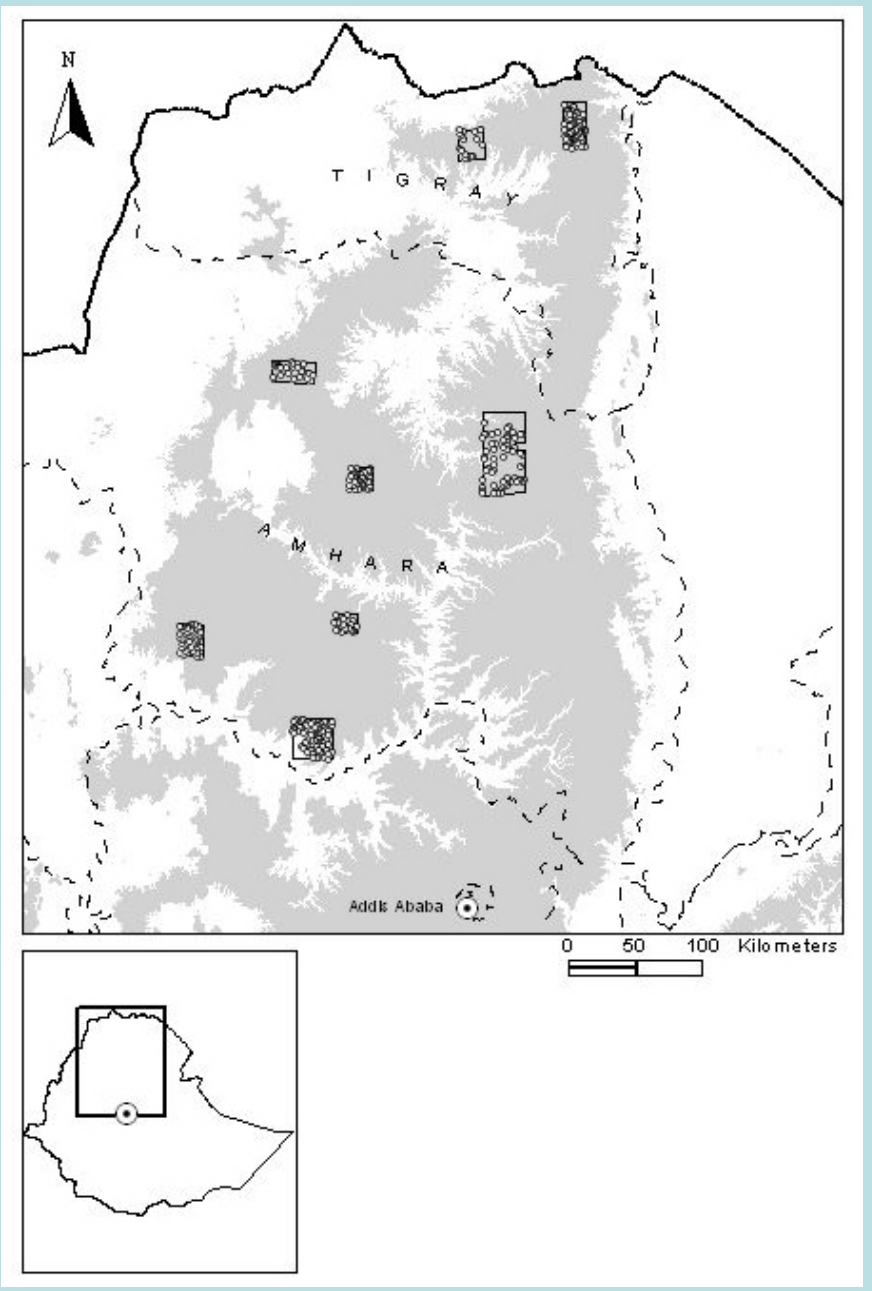




\section{Results}

\begin{tabular}{|c|c|c|c|c|}
\hline & North $(n=155)$ & & South $(n=239)$ & $P$ \\
\hline Mean patch size (ha) & $2.81(0.69)$ & & $2.26(0.31)$ & 0.271 \\
\hline Mean patch core area (ha) & $0.59(0.18)$ & & $0.32(0.14)$ & 0.238 \\
\hline Patch density (patches per ha) & $0.43(0.11)$ & & $0.46(0.08)$ & 0.801 \\
\hline Edge density ( $\mathrm{m} / \mathrm{ha})$ & $342(55)$ & & $317(43)$ & 0.727 \\
\hline Core index $(\%)$ & $23(12)$ & & $5(10)$ & 0.308 \\
\hline Forest index (\%) & $0.18(0.10)$ & & $0.31(0.08)$ & 0.346 \\
\hline Mean perimeter: area ratio $\left(\mathrm{m} / \mathrm{m}^{2}\right)$ & $0.066(0.003)$ & $>$ & $0.048(0.002)$ & $<0.001$ \\
\hline Mean shape index & $1.65(0.04)$ & $>$ & $1.4(0.03)$ & $<0.001$ \\
\hline Mean fractal dimension & $1.38(0.01)$ & $>$ & $1.33(0.01)$ & $<0.001$ \\
\hline Patch isolation ( $m$ to nearest neighbor) & $1993(92)$ & & $1887(74)$ & 0.329 \\
\hline Aspect & $F(N W>S E ; P<0.05)$ & & $F(N W=S E ; P>0.05)$ & \\
\hline Slope $(\%$ & $8.3(0.5)$ & $>$ & $4.7(0.4)$ & $<0.001$ \\
\hline Church-patch centroid distance (m) & $66(6)$ & $>$ & $36(5)$ & $<0.001$ \\
\hline
\end{tabular}


- Northern forests

- More complex shape (PAR, SI, FD)

- On steeper slopes

- More on NW slopes

- Ex-centric churches (churches at the edge)

- Southern forests

- Simple shape, often circular, often with a radius of $\sim 100 \mathrm{~m}$

- On small mountain tops

- Church central

- Almost on a regular grid in the landscape 


\section{Results}

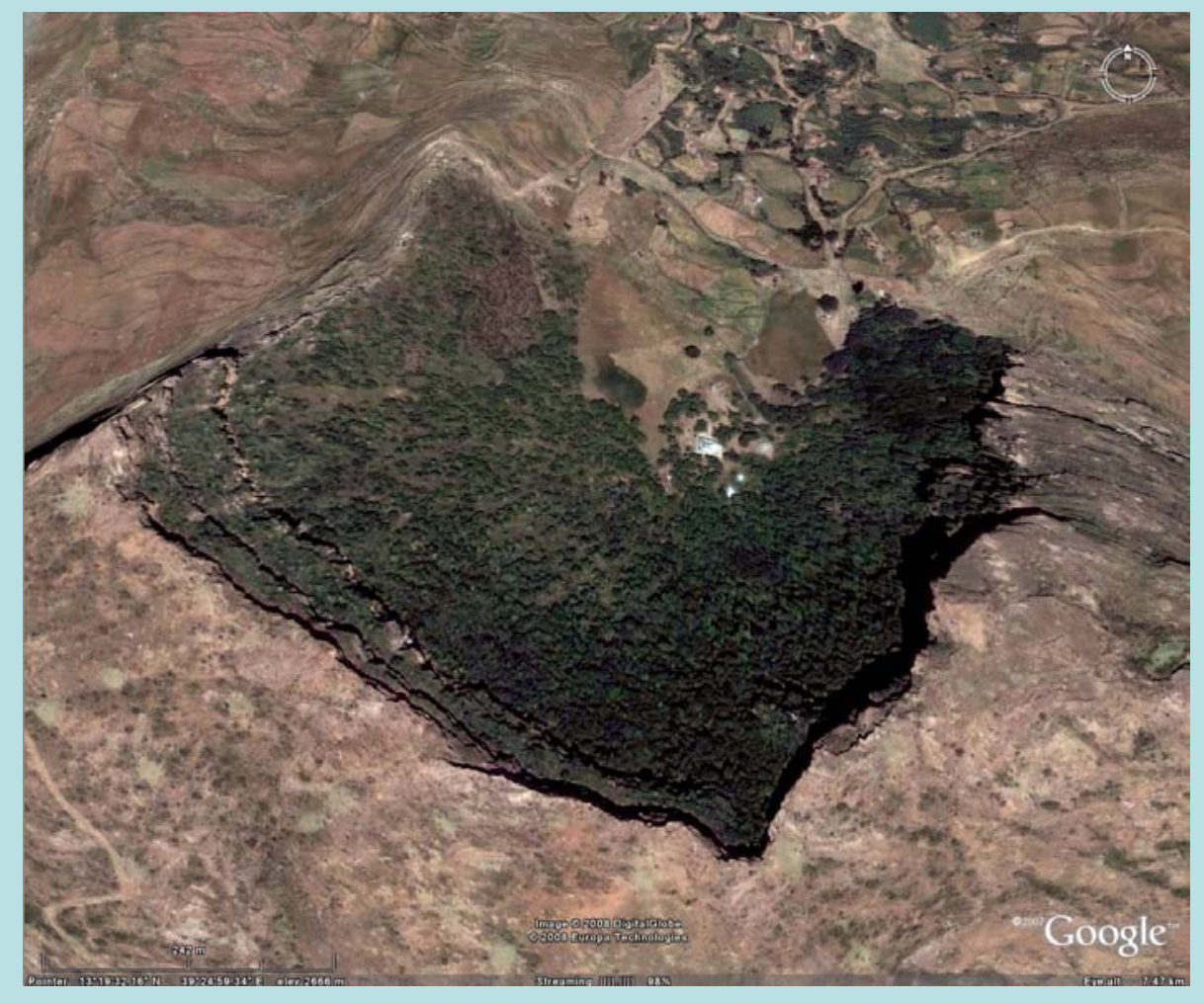

Typical northern church forest

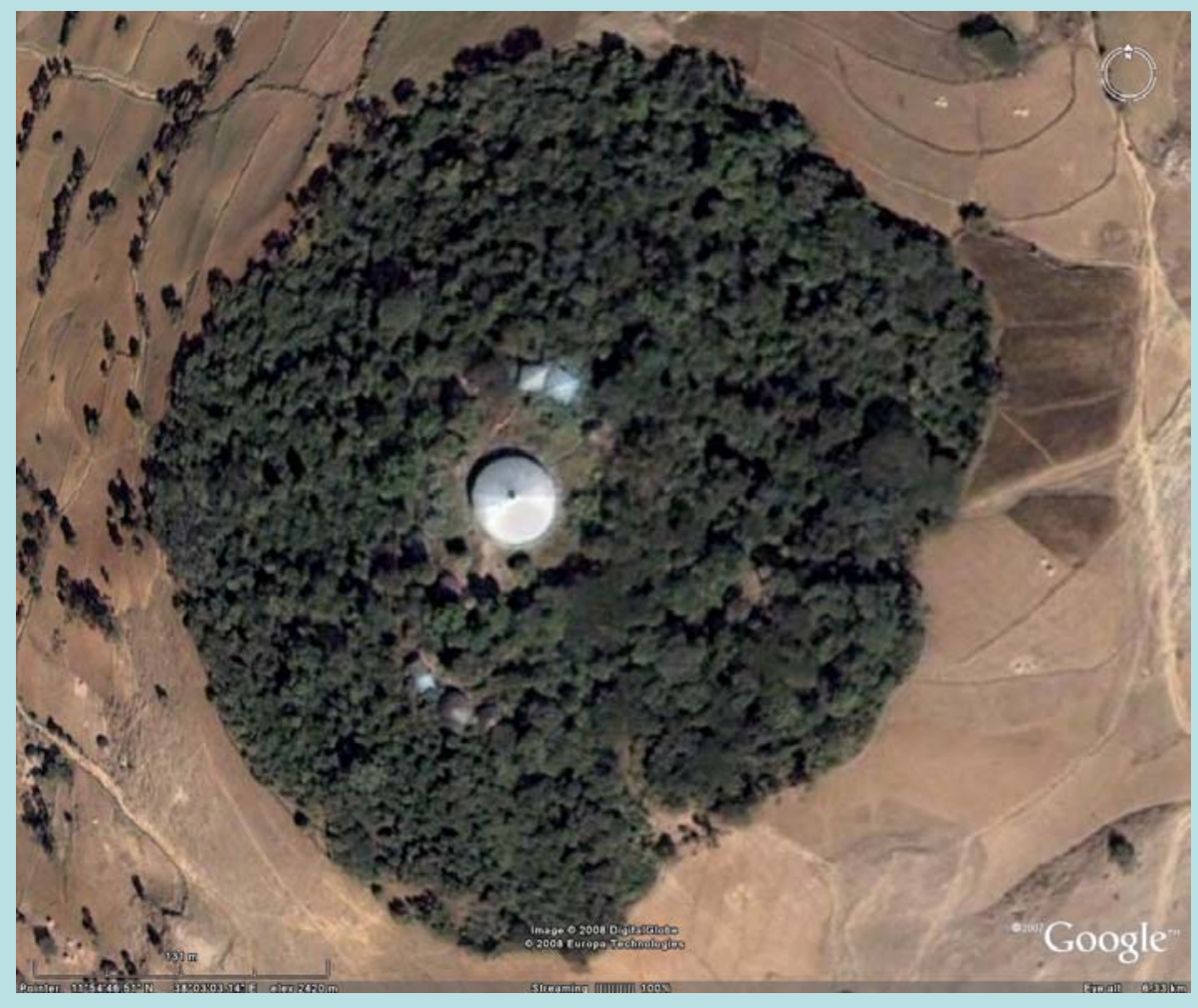

Typical southern church forest 


\section{Discussion}

- Shape, not size, reflect historical deforestation pattern

- North: church forest protected remnant forest patches after large scale deforestation of the landscape (thus, on steep, drier slopes)

- South: church forests protected designated forest patches in a forested landscape, prior to large scale deforestation

- Results consistent with 'roaming capitals of Ethiopia' 


\section{Discussion}

- 'Old capitals': Axumite period

- Large deforestation prior to arrival of Christianity

- Churches were established in deforested land

- Church forests protected 'what was left'

- Mainly secondary forest

- 'Newer capitals': Gondarine period

- Colonization of the land

- Church as a means to control the land

- Regular pattern of regular churches

- More likely to represent primary forest

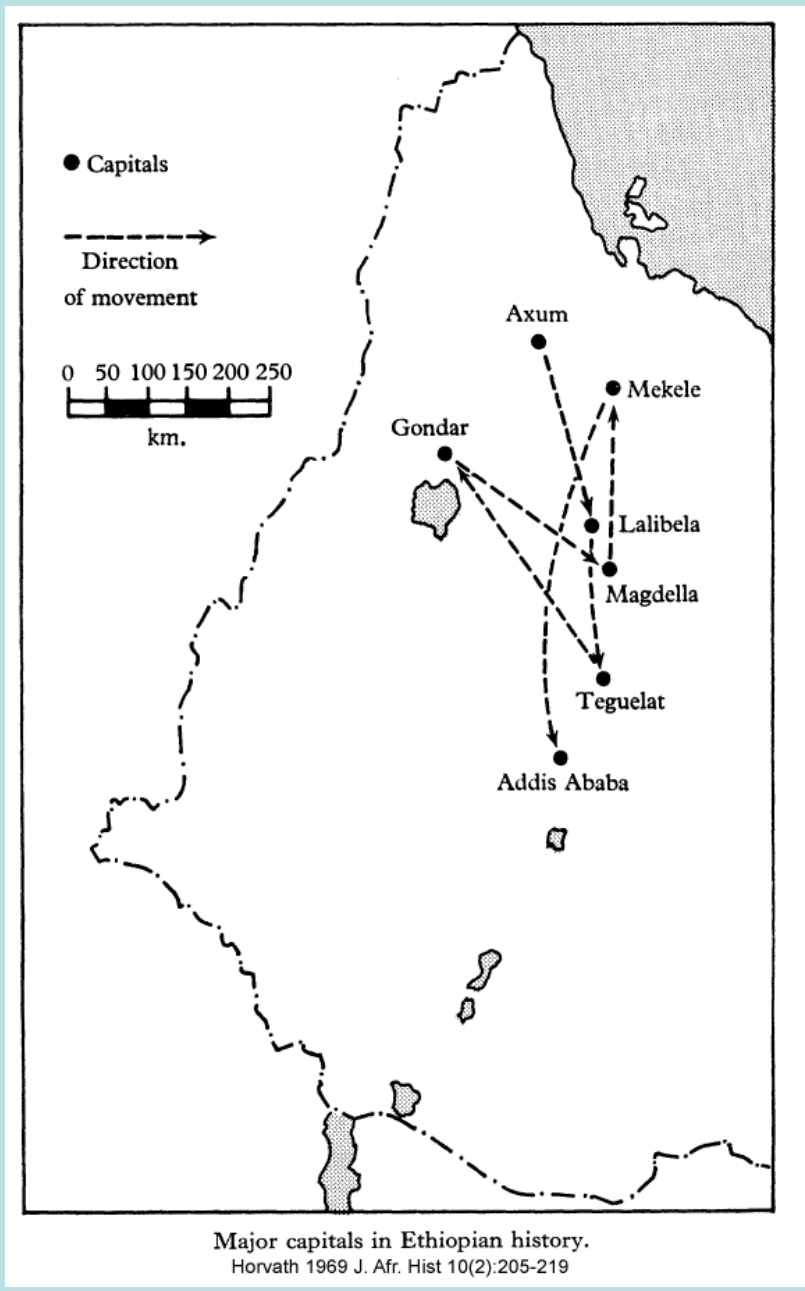




\section{Discussion}

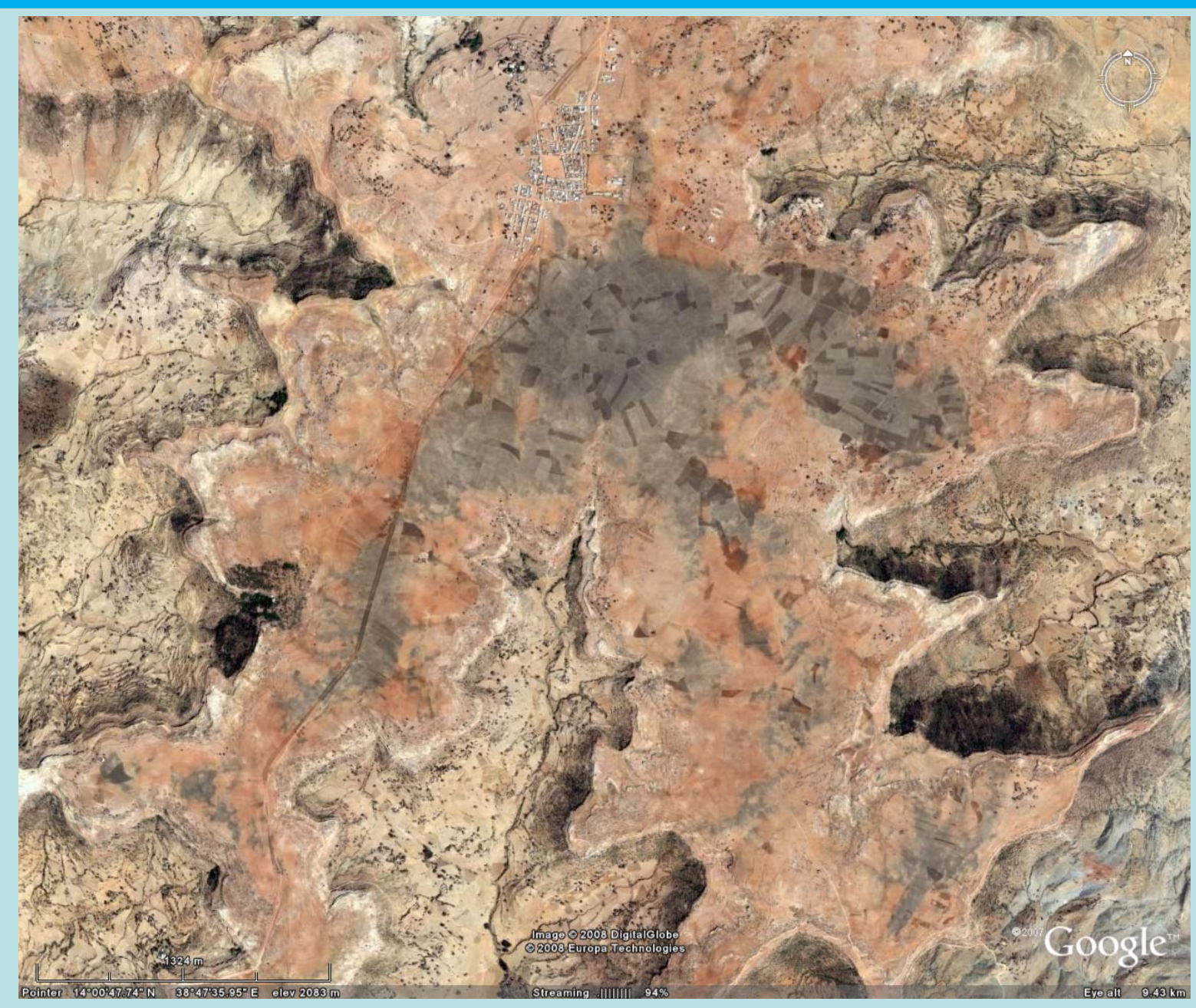

Northern forests on NW slopes (Axum) 


\section{Discussion}

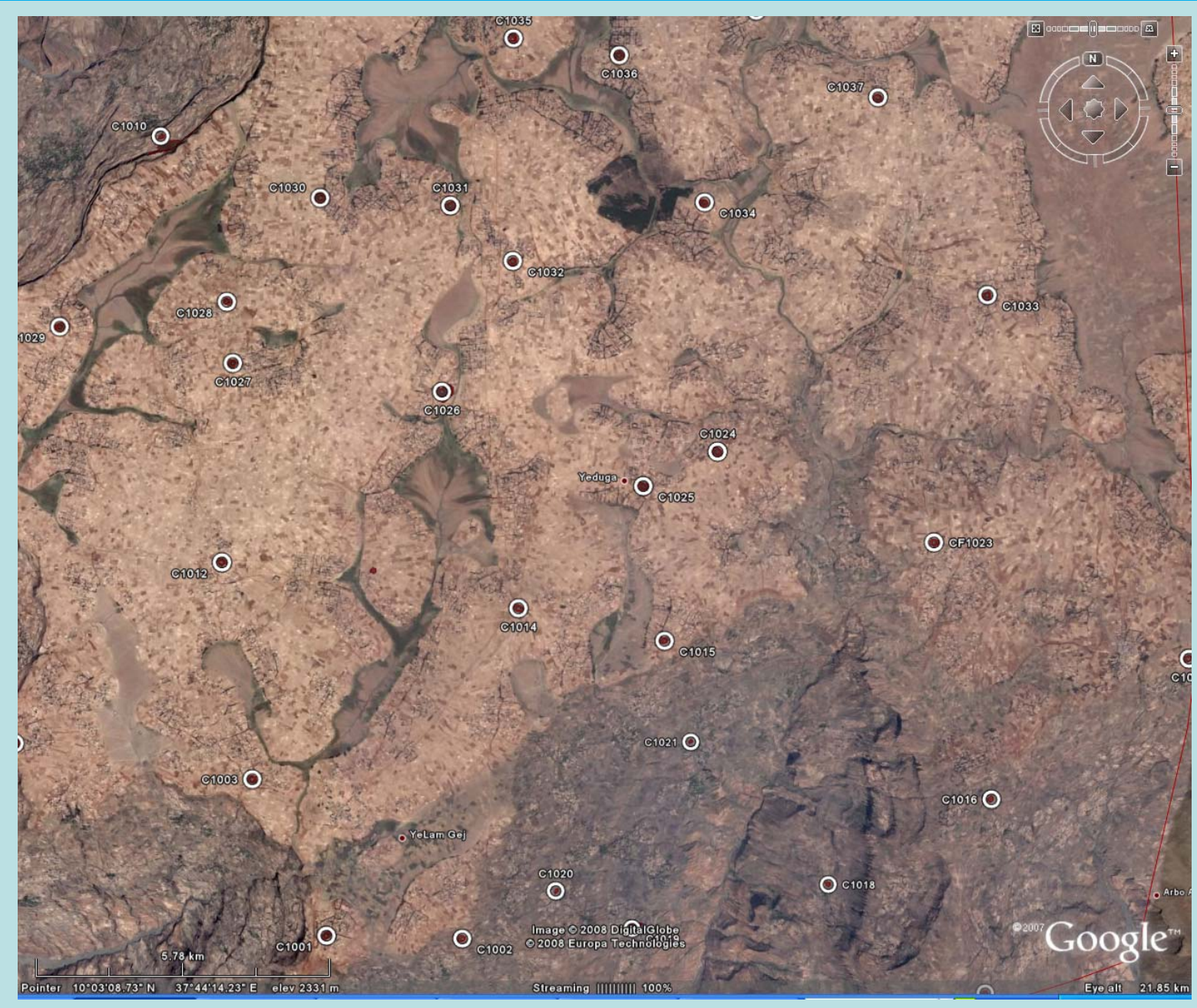

\section{Southern forests, regularly spaced (Debre Markos)}




\section{Discussion}

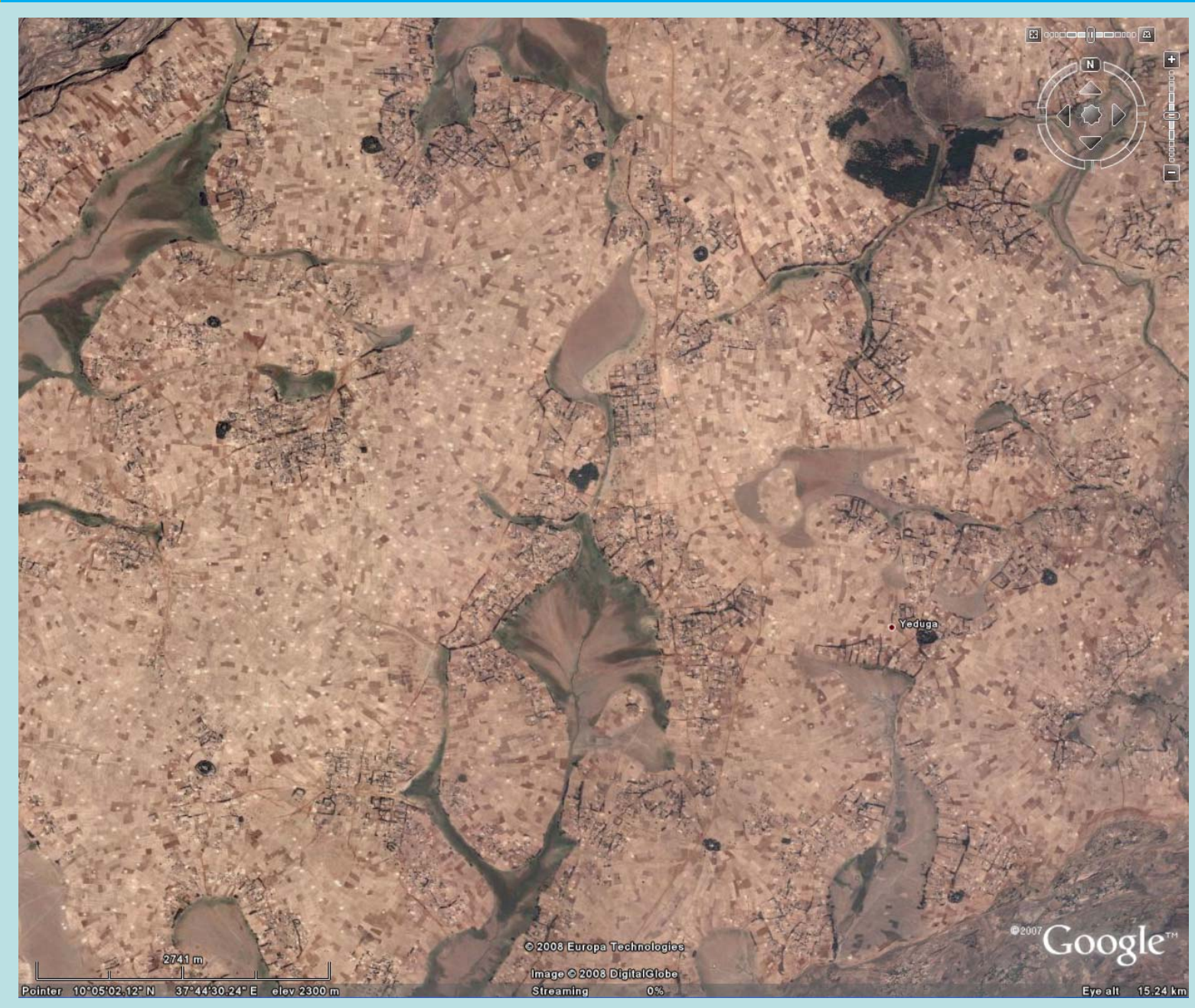

\section{Southern forests: churches on $3 \times 3 \mathrm{~km}^{2}$ grid}




\section{Discussion}

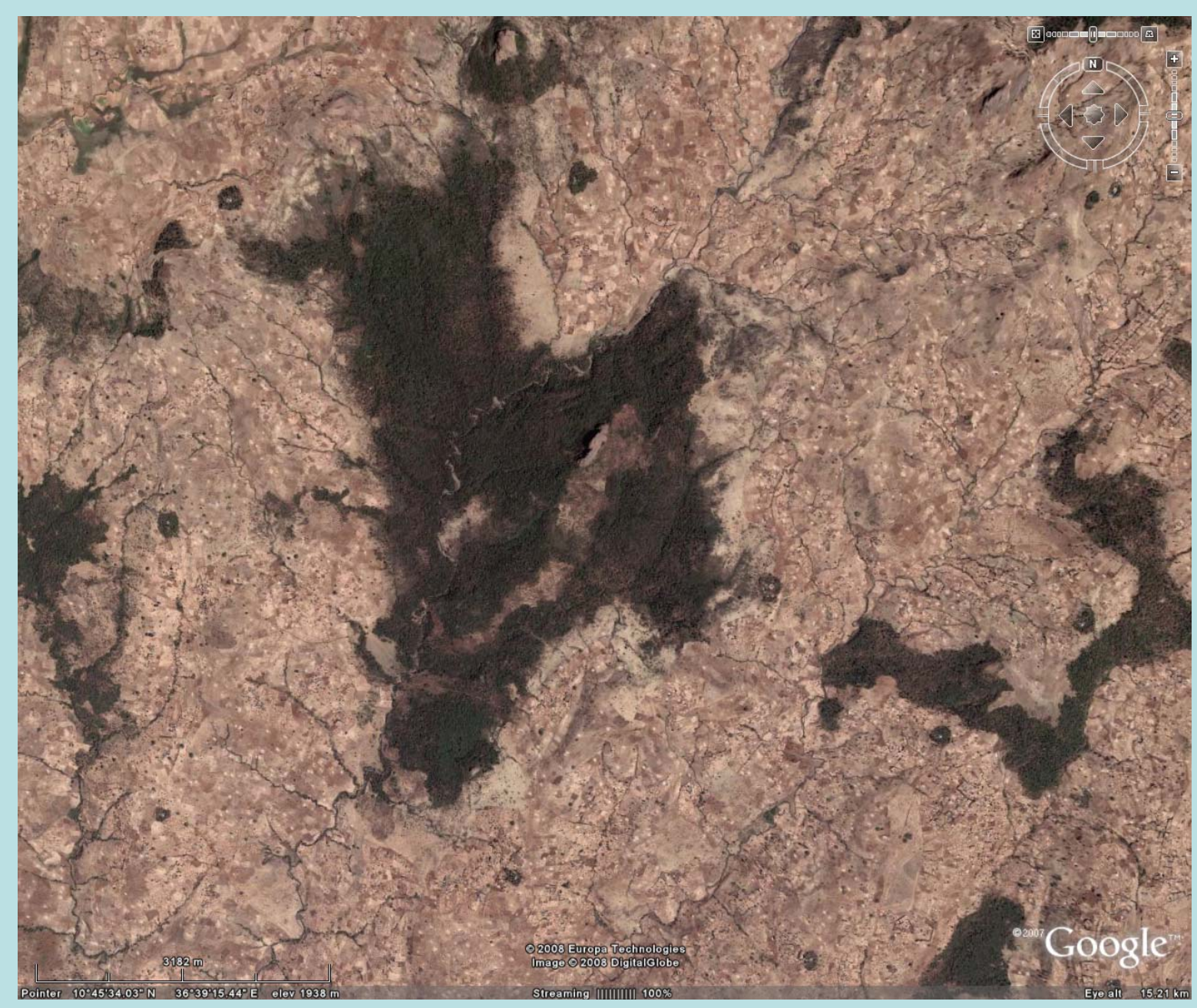

Southwestern forests: $3 \times 3 \mathrm{~km}^{2}$ grid and remnant of the original forest 


\section{Conclusion}

- Historical deforestation patterns

- Linked to historical development of the highlands

- Church forests have different origins

- North and northeast: conservation after fragmentation

- South and southwest: conservation before fragmentation

- Differential conservation status requires differential management

- Conservation of primary species a focus in the SW

- Restoration of primary species in secondary forest a focus in the NE

- Forest expansion needed in all regions: fragments very small (2.5 ha) and forest cover too low (0.2\%) 